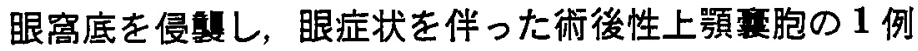

前田憲昭・佐藤光信・杉 政和 - 吉田秀夫

綿谷和也・梁川哲雄・宮崎 正

\section{A case report of postoperative maxillary cyst which invaded the orbital cavity}

\author{
Noriaki MAEdA - Mitsunobu SAto - Masakazu Sugi - Hideo Yoshida \\ Kazuya Watatani - Tetsuo Yanagawa - Tadashi Miyazaki
}

緒

言

術後性上顎蘶胞は, 慢性副鼻腔疾患の根治手術後, 長 い年月の間に, 残存した洞粘膜あるいは粘液腺の一部が

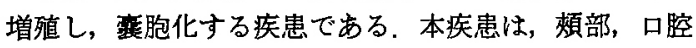
前庭部の腫脹ならびに同部の疼痛等を主訴とする場合が 多く，そのため口腔外科を受診する頻度が非常に高い．

しかし，術後性上頸襄胞で眼球を圧迫するなど，眼窩に 異常をきたした症例は非常に少ない

最近われわれは，術後性上頢襄胞で眼球が上転すると いら，きわめてまれな症例に遭遇したので報告する。

\section{症例}

患 者: 38歳 男性.

初 診: 昭和52年11月⿴日.

主 訴：左上顎臼歯部腫脤。

家族歴：特記事項なし。

既往歴：約22年前に，両側上顎洞の僈性副鼻腔炎に罹 患乙，上顎洞根治術をうけている。術後より最近にいた るまで，同部に特別な自覚症状を認めていない，なお， 幼少時よりアレルギー性鼻炎に䧹患し成年期まで通院加 療をらけ，現在でも時々水様性鼻汁の漏出を認めるとい 5 .

現病歴：昭和 52 年 10 月末に左上顎臼歯部に鈍痛を認 め，某医を受診し，急性歯髄炎との診断で左上枵第 1 大 曰崡の冠撤去怙よび歯内療法処置をうけた，その急性症 状は消退するも, 数日後, 左上顎犬歯窝に急速な腫脹を きたし，同医にて切開排膿の処置をらけたが軽快せず，

大阪大学莐学部口腔外科学第 1 丵座(主任:宮崎 正 教授)

The 1 st Department of Oral and Maxillofacial Surgery Osak University Dental School (Chief: Prof. Tadashi Miyazaki)

受付日：昭和54年 2 月15日
本学を紹介されて来院した

初診時所見：左側煩部にびまん性の遁脹をきたしてい る以外，顔面には变化を認めない，膑内所見として，左 側第 1 , 第 2 小臼歯の頉側根尖部に幅 $2 \mathrm{~cm}$, 長さ $3 \mathrm{~cm}$

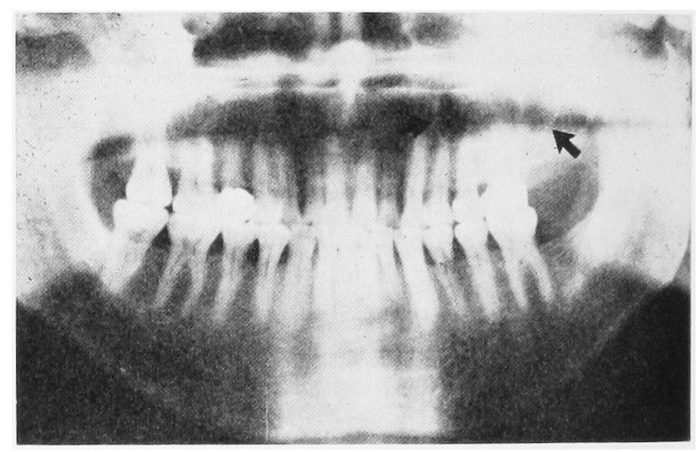

写真 1

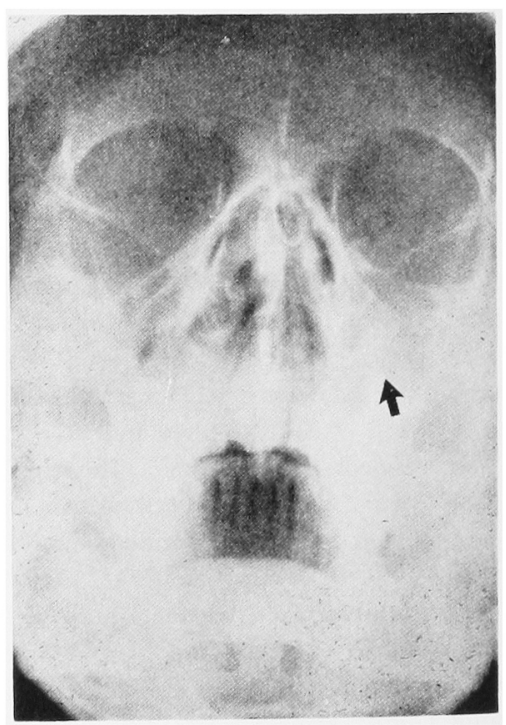

写真 2 
表 1 臨床検查成績

\begin{tabular}{|c|c|c|c|}
\hline & $\begin{array}{l}\text { 昭和52年 } \\
11 \text { 月 } 16 \text { 日 } \\
\end{array}$ & $\begin{array}{c}\text { 星和53年 } \\
6 \text { 月20日 } \\
\end{array}$ & 単 位 \\
\hline 赤血球 & 502 & 542 & $\times 10^{4} / \mathrm{mm}^{3}$ \\
\hline 白血球 & 8,700 & 7,000 & $/ \mathrm{mm}^{3}$ \\
\hline 血色素量 & 14.8 & 16.0 & $\mathrm{~g} / \mathrm{d} l$ \\
\hline 血球容䅪 & 43.7 & 46.8 & $\%$ \\
\hline 百分率 (\%) & & & \\
\hline 好 中 球 & 55 & 62 & \\
\hline 好塩基球 & 0 & 0 & \\
\hline 好酸球 & 4 & 0 & \\
\hline リンパ球 & 37 & 32 & \\
\hline 単 球 & 4 & 6 & \\
\hline 出血時間 & & & 単 位 \\
\hline 1 次 & 15 分 30 秒 & 5 分 00 秒 & \\
\hline 2 次 & 1 分 10 秒 & 出血せず & \\
\hline 血小板数 & 28.6 & 18.9 & $\times 10^{4} / \mathrm{mm}^{3}$ \\
\hline $\begin{array}{l}\text { 粘着率 } \\
\text { 凝集 能 }\end{array}$ & 99 & $\begin{array}{l}77 \\
\quad \ldots \leq-\end{array}$ & $\%$ \\
\hline $\mathrm{ADP}$ & 65 & -96 & $\%$ \\
\hline $\begin{array}{l}\text { コラーゲ } \\
\text { У }\end{array}$ & 72 & 83 ה" 83 & $\%$ \\
\hline 血餅収縮時間 & 60 分以内 & 30 分以内 & \\
\hline PTT & 36 & 36 & 秒 \\
\hline $\begin{array}{l}\text { プロトロンビ } \\
\text { ソ時間 }\end{array}$ & 100 & 87 & $\%$ \\
\hline 線溶現象 & $51 \mathrm{~mm}$ & $(-)$ & \\
\hline $\begin{array}{l}\text { フィブリノー } \\
\text { ゲン }\end{array}$ & 286 & N.D. & $\mathrm{mg} / \mathrm{d} l$ \\
\hline 邢機能 & & & \\
\hline 総蛋白量 & 6.83 & 7.74 & $\mathrm{~g} / \mathrm{d} l$ \\
\hline フルブミン & 4.35 & 4.50 & $\mathrm{~g} / \mathrm{d} l$ \\
\hline GOT & 17.42 & 18.35 & Karmen U. \\
\hline GPT & 13.05 & 15.29 & Karmen U. \\
\hline ALP & 9.10 & 10.89 & K-A.U. \\
\hline
\end{tabular}

の発赤を伴った粘膜の腫脤を認め, 一部に波動を触知 し，骨欠損の存在を認めた。左側上顎犬歯の根尖部付近 に纺新鮮な切開創を認めたが，膿汁などの排泄はなかっ た. 歯䯣猃断器によるテストでは|3 4 は生活齿であり, 吕6は失活歯で，百の口蓋根は開放されていた。炎症症 状を示す組織恃 56 6 敬頪移行部に限局しており，三叉 神経第 2 枝領域での神経圧迫あるいは神経炎の症状は認 められなかった，左側の释腔の閉鎖感は強いとのことで あった。

初診時 $\mathbf{X}$ 線写真所見 : 問診および臨床経過より術後性 上䫑粪胞を疑いX線撮影を行った。 パノラマ写真（写真 1）では，左側上顎第 2 小田歯拈よび第 1 大田歯の根尖
表 2 眼科所見

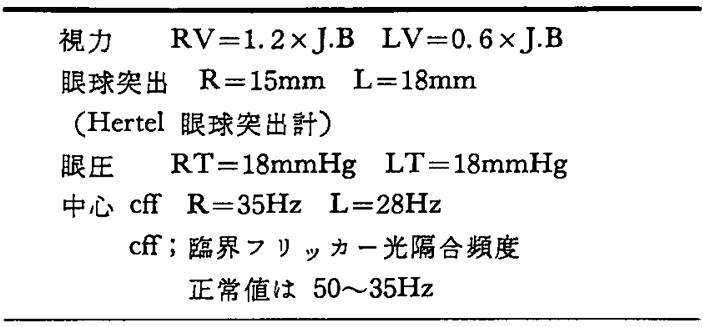

部を底部として，上效洞内に周囲組織と明瞭な境界を有 する鶏卵大の X線透過像を認めた。外側壁は煩骨陥凹部 に，内側壁は犬歯窩にいたり，上靧洞内をほぼ満たして いた. Waters 法による撮影では（写真 2)，透過像の上 縁は上顎骨眼窩下縁の直下まで及んでいたが，眼窩下孔 周辺の吸収像は認めなかった。 正中側では，中鼾甲介が わずかに正中側に圧迫されていた。デンタル撮影では 156の歯根周囲の白線は消失し，すべての根は病巣に穿 孔していた。

\section{処置および経過}

臨床所見およびX線写真所見より，術後性上顎整胞と 診断された．治療は再発する症状を軽減する目的で上 5 の 歯䯣腔は開放され，排膿が行われた。内容は帯黄褐色の 粘稠な液体であり感染が認められたため, セフォロスポ リン系の抗生物質であるケフレックス（塩野義製薬，大 阪）が1日 $1 \mathrm{~g}$ で投与された。 その結果，3 日後には全 身および局所の症状は改善され，整胞の摘出が計画され た. しかし，止血検查において，出血時間が 14 分 30 秒

（表 1）と延長していることが判明し, 出血性素因の存 在が疑われたため，外科的処置を延期した，病巣に対し ては対症療法を行いつつ, 止血機構の検査を継続した結 果, 表 1 に示すごとく, 止血機構における器質的な病因 は認められず，原因不明な一時的異常と考えられた．昭 和53年 3 月, 検査で出血時間が 8 分 30 秒と短縮され, 手 術が予定され待機の状態にあった。 ところが同年 5 月 24 日になって, 左煩部の急速な腫脹と左眼よりの流淡, 視 力低下，視野狭窄を訴えて来院した．

\section{再診時臨床所見}

左顔面はびまん性に腫脹しておりその上縁は左下眼瞼 に，正中側は左鼻根部に及んでいた，特に鼻骨之涙骨の 縫合部では圧痛を認めるとともに，小指頭大の骨欠損を 思わせる部位が存在した。 外側は外眼角より浮腫状に頓 骨弓に及び，底部は口腔内の左上顎歯槽骨上，薑煩移行 部にあった，さらに眼窩下縁の腫脹のために眼球下制筇 の運動が制限され，眼球の下転が不能で上転したままと なっていた。 さらに压迫症状として視力が減退し, 視野 㹟窄，流涙を認めた，同時期の眼科所見は表 2 に記した と抢りであった。 


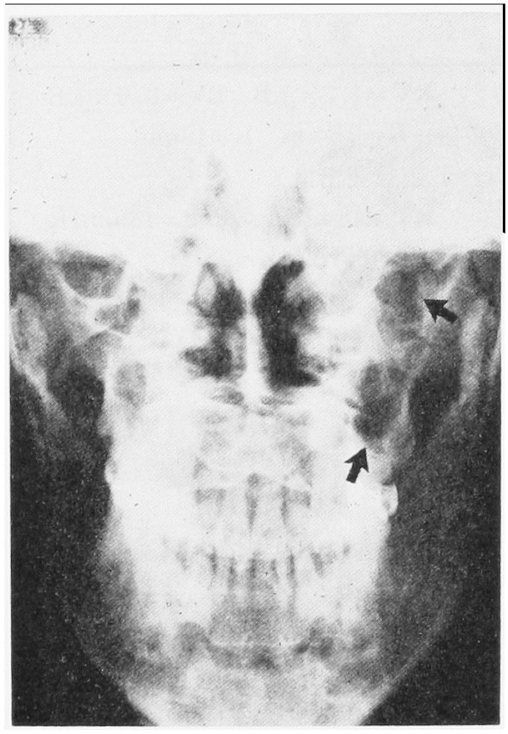

写真 3

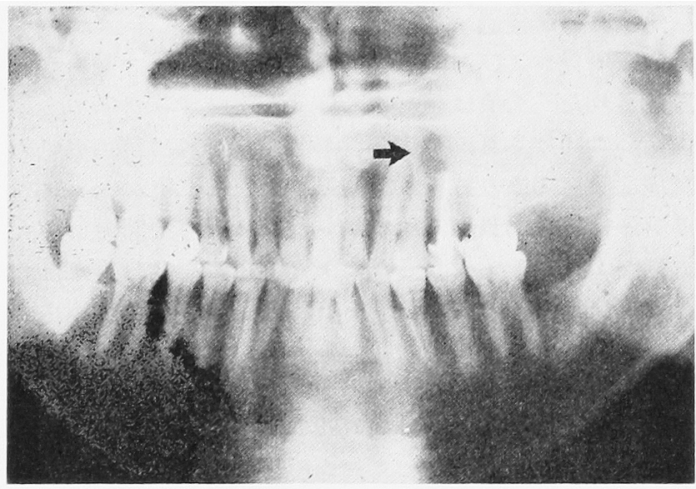

写真 5

\section{$\mathbf{X}$ 線所見}

後頭一前頭撮影像（写真 3）では腿窩下縁の骨吸収は 著明で，病巣が眼窩内に進展していることが認められ だそこで骨吸収および病巣の確認のため，矢状および 側方の断層撮影を行った，病巣は矢状方向で著明で，顔 面皮虚よりの深度が $1.5 \mathrm{~cm}, 2.5 \mathrm{~cm}$ で腿简下縁，眼窩底 の上顎骨の吸収が認められた（写真 4 ）が，樑度が $4 \mathrm{~cm}$

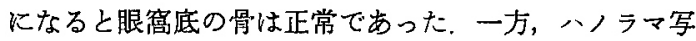
真像（写真 5)，Waters 法写真像（写真 6) では病巣の 上䫇結節内への進展と眼窩底への侵壟は諮められたが， 翼口蓋窩への陥入は認められなかった。

以上のような症状で再診の翌日，吕の根尖部より試験 穿刺を行い，前回之同様の内容液を $5 \mathrm{~m} l$ 吸引した。 ま た，この処置により眼球の運動制限が緩和されることが 明らかとなり，昭和53年 6 月日日なると，出和傾向も 改善された（表1）ので，手術を施行した。ただ，断

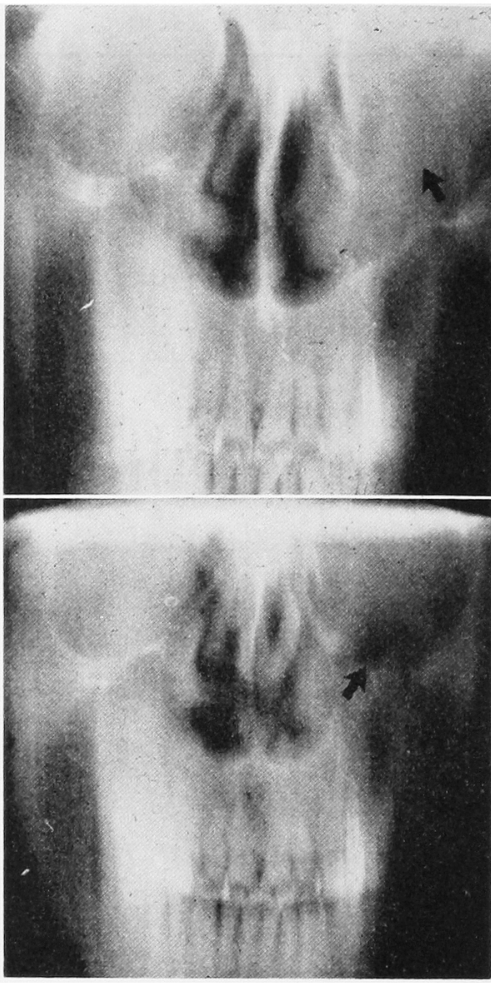

写真 4

a : $1.5 \mathrm{~cm}, \quad b: 2.5 \mathrm{~cm}$

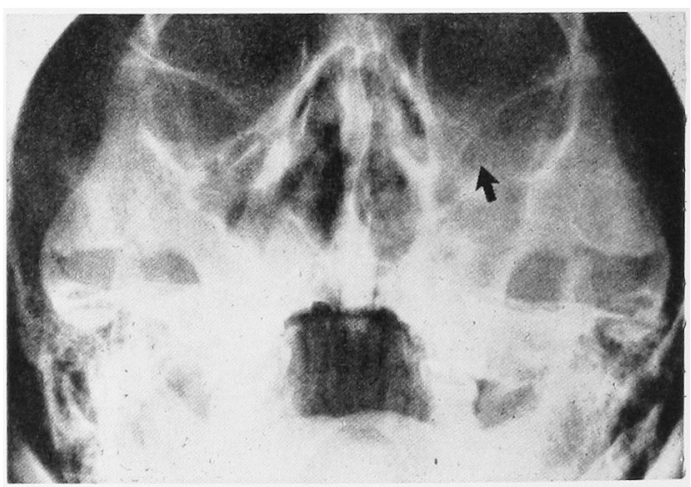

写真 6

層X線所見および強診による骨欠損の存在は，単に桽胞 とのみ考えることはできず，むしろ上顎骨内に発生した 悪珄腫瘍を思わしめた。 そこで，術前に衰胞内の内容液 を穿刺する際，一部谼胞壁の組織を採取し，病理切片と したが，組織学的診断では感染上皮組織であった。

手術術式：昭和53年 7 月日日，手術は全身麻酔下で施

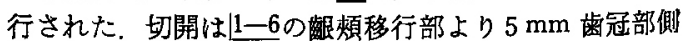
の紫槽骨上に加えられ，次に鈍的に骨膜下の娳離が行わ れ，吕6の骨欠損部にいたった，同部の欠損は拇指頭大 


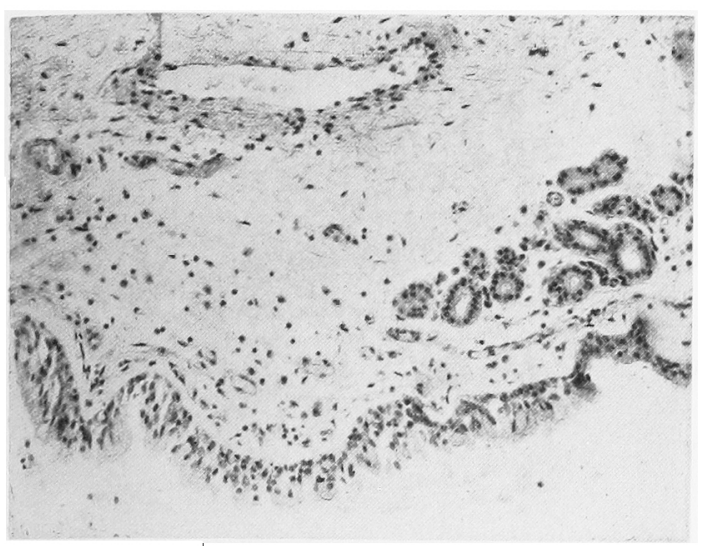

写真 7

(H.E. 染色 $\times 100)$

で周囲骨の削除を行らことにより，上類洞を明視下に確

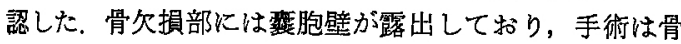
内壁と褒胞壁を分離することにより，側方，上方，正中 側飞進められたが，一部で骨と癒着していたために，内 容花が漏出した。 上方部は眼窝下縁で指示頭大の骨欠損 を認め，上顠洞と眼球は襄胞壁でのみ境されていた，壁 を摘出する際，眼球は容易に触診することができた，後 万では固有の上筫洞壁の存在を認めたが，正中側では眼 墖下縁の骨欠損部より節骨蜂栄に連続して䔟行する肥厚 した粘膜を認めた。一部涙骨と番骨の縫合部付近には, 小指頭大の骨欠損を認め，粘膜下には膿汁が約 $5 \mathrm{~m} l$ 貯 留していた。この夜の粘稠度は他部のものより高かっ た.

手術は上䫑洞根治術に準してて行われ，洞内の提爬後， 大量の生理食塩水で洗浄し, テラマイシン軟高を塗布し た長さ約 $50 \mathrm{~cm}$ のガーゼをタンポンとして挿入し，左奥 柾底に対孔を形成，タンポンの一端を取り出して顔面に 固定した，その後，切開部を縫合し手術を終了した．

\section{手術時の病理組蟣所見}

手術時得られた襄胞壁の病理所見は, 感染した上皮組

織であり，一部ガラス様変性を起こしているとともに，

周围結合組織内には小唾液腺が多数みられた(写真 7).

\section{術後経過}

術後，ただちに眼球の運動制限は解除され，頓部には 一眭的な反応性の腫脹をきたしたものの, 経過は良好で すった３か月を経過した時点の観察においてる，眼症

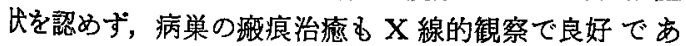
ろ.

\section{考察}

慢性副鼻腔炎むるいは術後性上㖽栾胞の炎症が眼窩に
及び，眼球突出，視力障害，複視，眼痛，眼瞼腫脤，眼 球運動障害，流涙などの症状を示す例は，Thoma1)，山

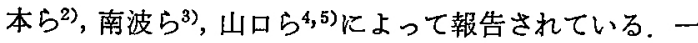
般に炎症が眼简に波及する経路は篩骨洞を経るむの2)， 血行あるいはりンパ行性，または先天性骨間吵》之考点 られているが，本症例では谼胞が膨大して眼窩底の骨を 吸収し，直接眼球を正迫していた，したがって眼裔に及 ぼす症状も上に述べたもののほか，視神経機能（中心 cff）の低下がみられた，しかし，すべての症状は，隹胞 による物理的な圧迫症状であったために，術後にはただ ちに正常に復した。 また術前の上顎骨断層X線写真所見 では，半月裂溝に開口する上顎洞自然孔付近より眼窩底 にいたる著明な骨吸収を認め，覀性腫湯の所見を思るせ た．そこで，術前には上領歯槽骨面の骨欠損部より，術 後には骨吸収の著明な部分よりの病理組織片の採取を行 ったが，結果は感染上皮の存在のみで悪性像住認められ なかった。

今回の症例の発生の機序を考えると，15年前に行われ た慢性副鼻腔炎の根治手術時に残存した上皮が，長い年 月を経て垔胞様に增大するとともに，生来䍜患していた アレルギー性鼻炎で，自然孔周囲に焱症が綝り返され， 術後の治痹が阻害され，感染が上䫇洞内に拡大したと思 われる．特に自然孔相当部より節骨蜂巣を被覆する粘膜 は肥厚し，一部には膿汁の詝留を認めたことは，同部お よび眼窩底部の骨吸収が著明であったことと一致する所 見であった。すなわち，本症例は術後に発生した上䪽栾 胞と従来からのアレルギー性鼻炎がなんらかの機作住よ って関連し，発生したものと考えられる。

なお本症例の加療にあたり，貴重な眼科所見とご助言 をいたたいた，大阪大学医学部眼科学教室森山穂樻先生 に深謝いたします。

\section{引用 文 献}

1) Thoma, K.H.: Oral Surgery 2 nd ed. Mosby Co, St Louis, 1952, p 759.

2）山本美朗，他：眼球实出を来たした両側很後煩 部藻胞の 1 例. 日口外誈 21：66 1975.

3）南波 正，他：眼球突出を来たした蒾性上颚洞 炎の 1 例。 日口外誌 21：69 1975.

4）山口宏也：最近経豎した鼻副鼻腔及び眼窝合併 疾患にっいて。耳鼻 18: 2671972.

5）木暮山人：術後性上罰胞胞臨床的研究. 耳展 20: 3011977. 